DOI https://doi.org/10.30525/978-9934-588-90-7-9

\title{
КОДИФІКАЦІЯ ПУНКТУАЦІЙНИХ НОРМ ВЖИВАННЯ РИТМОМЕЛОДІЙНИХ РОЗДІЛОВИХ ЗНАКІВ В НОВІЙ РЕДАКЦІЇ «УКРАЇНСБКОГО ПРАВОПИСУ»
}

\author{
Омельчук С. А. \\ доктор педагогічних наук, дочент, \\ заслужений діяч науки і техніки України, перший проректор, \\ професор кафедри слов 'янської філології та світової літератури \\ імені професора О. Мішукова \\ Херсонський державний університет \\ м. Херсон, Украӥна
}

Ця розвідка $є$ продовженням наукових пошуків автора, присвячених зокрема дослідженню особливостей кодифікації пунктуаційної норми вживання тире в новій редакції «Українського правопису» на основі порівняння 3 виданнями правопису 1993-2015 pp. [1]. Закономірно з'ясувати, як кодифіковано норми вживання ритмомелодійних розділових знаків (крапки, знака оклику, знака питання, трьох крапок) у редакції «Українського правопису» 2019 р.

Порівнюючи правописи 1993-2015 рр. з новою редакцією правопису 2019 р., констатуємо: якщо в редакціях правопису 1993-2015 pp. [2; 3] в окремих параграфах за видами розділових знаків (§ 115 «Крапка», $\S 116$ «Знак питання», § 117 «Знак оклику», § 122 «Крапки») міститься 15 правил з 11-ма примітками до них, то в новій редакції правопису [4] в $\S 155$ «Крапка», § 156 «Знак питання», § 157 «Знак оклику», § 162 «Три крапки, або крапки» збільшено й кількість пунктуаційних правил (з 15 до 17) і приміток до них (з 11 до 15) (таблиця).

Таблиця

Кількість пунктуаційних правил уживання ритмомелодійних розділових знаків в правописах 1993-2015 і 2019 рр. в.

\begin{tabular}{|c|c|c|c|c|}
\hline \multirow{2}{*}{$\begin{array}{c}\text { Видд } \\
\text { розділового } \\
\text { знака }\end{array}$} & \multicolumn{2}{|c|}{ K-ть пунктуаиійних правил } & \multicolumn{2}{|c|}{ К-ть приміток до правил } \\
\cline { 2 - 5 } & $\begin{array}{c}\text { правописи } \\
1993-2015 \mathrm{pp} .\end{array}$ & $\begin{array}{c}\text { правопис } \\
2019 \mathrm{p} .\end{array}$ & $\begin{array}{c}\text { правописи } \\
1993-2015 \mathrm{pp} .\end{array}$ & $\begin{array}{c}\text { правопис } \\
2019 \mathrm{p} .\end{array}$ \\
\hline Крапка & 5 & 2 & 2 & 5 \\
\hline $\begin{array}{c}\text { Знак } \\
\text { питання }\end{array}$ & 2 & 4 & 3 & 5 \\
\hline Знак оклику & 5 & 5 & 4 & 4 \\
\hline Три крапки & 3 & 6 & 2 & 1 \\
\hline Усього & $\mathbf{1 5}$ & $\mathbf{1 7}$ & $\mathbf{1 1}$ & $\mathbf{1 5}$ \\
\hline
\end{tabular}


Порівняльний аналіз умов уживання ритмомелодійних розділових знаків (крапки, знака оклику, знака питання, трьох крапок) в правописах 1993-2015 і 2019 рр. в. дає підстави зробити такі узагальнення:

1. Кодифікація пунктуаційної норми вживання крапки. У новій редакції правопису зменшено кількість правил 3 5-ти до 2-х. По-перше, це пов'язано з тим, що 1-ше, 2-ге і 4-те пунктуаційні правила правописів 1993-2015 рр. в. у новій редакції правопису об'єднано в одне правило. По-друге, це правило доповнено новими умовами вживання крапки:

- у називних реченнях: Зима. Холоднеча. Засніжений ліс (М. Стельмах);

- між прізвищем автора, назвою його твору, назвою міста: Олесь Гончар. Собор. Київ, 1968;

- у реченнях 3 називним відмінком теми (уявлення): Дванадиятирічна шкільна освіта. Це добре чи погано? (заголовок газетної публікації).

Водночас збільшено кількість приміток до основних правил (з 2-х у правописах 1993-2015 рр. в. до 5-х у правописі 2019 р. в.). Зокрема, у примітці 1 додано умови, за яких крапку не ставимо: «...на титульних аркушах книжок, журналів тощо - після імені та прізвища автора, назви твору, назв видавництва i місця видання i т. ін.» [4, с. 198]. Примітка 2 також $є$ новою в правописі 2019 р. й регламентує вживання крапки після цитат або іншої текстової ілюстрації перед прізвищем автора чи вказівкою на їхнє джерело, наведене в дужках. Примітки 3-4 указують на ті частини правопису, у яких ідеться: а) про вживання крапки в кінці вставлених речень у дужках (примітка 3); б) про вживання крапки після зауважень у дужках у межах певної цитати на зразок «... (примітка наша. - Ред.) ...».

До того ж у цьому параграфі унормовано термінну лексику: якщо в правописах 1993-2015 рр. в. йшлося про крапку «як знак незакінченості слова на письмі» [3, с. 152], то в правописі 2019 року наголошено на вживанні крапки в умовних графічних скороченнях.

2. Кодифікація пунктуаційної норми вживання знака питання. Редакція правопису 2019 р. в. регламентує вживання знака питання в 4-х правилах, замість 2-х - у правописах 1993-2015 рр. в.

До правила 1 додано дві нові примітки:

Примітка 3. Складну інтонацію питання / оклику передаємо на письмі двома відповідними знаками ?!

Примітка 5 указує на ту частини правопису, у якій можна дізнатися про написання після знака питання слів 3 малої літери. 
Новими також у цьому параграфі є: правило 2 про вживання знака питання в кінці вставленого речення або після вставленого слова (словосполучення), вимовленого з питальною інтонацією; і правило 4: «У відтворенні реплік діалогу цей знак може передавати не вимовлене одним із співрозмовників «німе запитання» (вираження нерозуміння, здивування, сумніву тощо): - Навіщя вам треба було ие робити?! - ???».

3. Кодифікація пунктуаційної норми вживання знака оклику. Незважаючи на те що кількість основних правил уживання знака оклику в правописах 1993-2015 і 2019 рр. в. однакова, проте, по-перше, у новій редакції окремі правила об'єднано в одне (наприклад, 1-ше і 2-ге 3 правописів 1993-2015 подано в правописі 2019 рр. в. одному правилі); по-друге, додано нове пунктуаційне правило, що регламентує вживання знака оклику в кінці вставленого речення або після вставленого слова (сполучення слів), вимовлених з окличною інтонацією (правило 4).

Правило 1, що регламентує вживання знака оклику в кінці речення, що вимовляємо з окличною інтонацією (часто це спонукальні речення), й у кінці окличного називного речення, зокрема в конструкціях з називним відмінком теми (уявлення), - доповнено новою приміткою 4: «В українській художній і публіцистичній літературі після слів зі знаком оклику досить звичайним було написання наступного слова 3 малої літери (якщо, на думку автора, це все було в межах одного висловлення), часто в конструкціях з інтонаційно розчленованими однорідними або повторюваними членами: Кляті! кляті! (Т. Шевченко); [Голос:] Гов, Лукашу, гов! го-го-го-го! A де ти? (Леся Українка). У сучасній правописній практиці в подібних випадках слід віддавати перевагу написанню з великої літери (лишаючи, звичайно, більшу свободу вибору для художньої літератури)» [4, с. 202].

Також у цьому параграфі правопису 2019 рр. в. закономірно замінено термін однослівне звертання на непоширене звертання.

\section{4. Кодифікація пунктуаційної норми вживання трьох крапок.} Насамперед у новій редакції правопису запропоновано термін три крапки як основний, замість терміна крапки, зафіксованого в правописах 1993-2015 рр. в. (це відбито в самій назві параграфа § 162 «Три крапки, або крапки»).

Докладніше, на відміну від попередніх редакцій «Українського правопису», виписано особливості вживання на письмі трьох крапок. Поперше, у правилі 1 додано нову позиції вживання трьох крапок: «У реченнях з називним відмінком теми (уявлення): Щастя... Хіба не думав про нього Степан? (В. Підмогильний)» [4, с. 241]. По-друге, третій абзац правила 1 відбиває зміст примітки до правила 1 правописів 
1993-2015 рр. в. По-третє, правила 3-5 є новими і стосуються таких особливостей уживання трьох крапок на позначення:

- несподіваного продовження чи завершення думки - 3 незвичним або й несумісним поєднуванням слів (часто в заголовках газетних заміток, нарисів, фейлетонів тощо): Вибори ... без вибору; зокрема, з використанням відомих цитат, крилатих висловів: ...І Щуку кинули у річку;

- розриву в оповіді, різкого переходу до нової думки (у художніх і публіцистичних текстах на початку речення - звичайно на початку абзацу): Летимо над колією над залізничною... Отакінька колія... Рейки, як дротики. < ..>

...Маленькі озеречка, маленькі лісочки, маленькі річечки, маленькі сільия. I все че там - під нами! (Остап Вишня);

- свідомої недомовленості, умовчання 3 певних причин: - Ходять тут усякі... - бурмоче дід (О. Донченко); - Ну, це вже ви того... прокинувся рибалка. - Це брехня (Ю. Яновський). 3 цією метою слова, що їх уважають грубими, образливими, непристойними, можуть подавати в тексті не повністю, а з випущенням певної частини їхнього графічного складу (після початкових літер або всередині слова) [4, с. 242].

Правило 6, що відповідає за змістом правилу 3 в правописах 19932015 pp. в., доповнено уточненням: «На позначення пропуску в цитованому тексті - після останнього слова перед пропуском або перед першим словом після пропуску, без дужок або в дужках, без інтервалу після слова і перед ним або з інтервалом» [4, с. 242] (уточнення ми виділили курсивом).

Отже, в «Українському правописі» 2019 р. пунктуаційні правила i примітки до них, що регламентують уживання в писемному мовленні ритмомелодійних розділових знаків (крапки, знака оклику, знака питання, трьох крапок), концептуально не є новими, вони носять здебільшого уточнювальну функцію 3 метою доповнення й систематизації пунктуаційних норм.

\section{Література:}

1. Омельчук С. Кодифікація пунктуаційної норми вживання тире в новій редакції «Українського правопису». Дивослово. 2019. № 10. С. $28-32$.

2. Український правопис. Київ: Наук. думка, 1993. 240 с.

3. Український правопис. Київ: Наук. думка, 2015. 288 с.

4. Український правопис. Київ: Наук. думка, 2019. 392 с. 